\title{
EP-685 The relationship of genetic factors to the development of nephrolithiasis in primary hyperparathyroidism (PHPT)
}

\author{
Authors: Peretokina EV ${ }^{1}$, Mokrysheva $N G^{1}$, Rozhynskaya L $\mathrm{Ya}^{1}$, Zacharova E $\mathrm{Yu}^{2}$ \\ Hospital: ${ }^{1}$ Department of neuroendocrinology and osteopathy, Endocrinology Research Centre, Moscow, Russia, ${ }^{2}$ Medical Genetics Research \\ Center, Moscow, Russia..
}

\section{Objective:}

Factors affecting the development of nephrolithiasis (NL) in PHPT actively studied. Studies have shown that polymorphisms CASR may be associated with rick of NL in patients PHPT. Expected the role of VDR polymorphisms in the development of kidney stones in the general population, but its importance in the pathogenesis of NL in patients PHPT unknown.

Objective: To assess the relationship of polymorphisms CASR and VDR with the development of the NL at PHPT

The study included 187 patients with PHPT (54 [49; 64] years), 110 with NL, 77 without. Exclusion criteria were genetically confirmed by multiple endocrine neoplasia syndrome type I or II, suspicion of MEN syndrome based on the identification of patients younger than 40 years PGPT two or more adenomas (hyperplasia) of the parathyroid glands, and / or entities pituitary, adrenal, pancreas, neuroendocrine tumors of the gastrointestinal tract), normocalcemic PHPT, severe chronic renal failure, hepatic failure, congenital anomalies of the kidney and urinary tract diseases, cancer and severe somatic diseases.

Groups did not differ in age $(\mathrm{p}=0.886)$ and $\operatorname{sex}(\mathrm{p}=0.15)$. All patients were examined: biochemical blood analysis (total and ionized calcium, phosphorus, creatinine to estimate GFR, alkaline phosphatase), the definition of a daily urinary calcium excretion, hormonal analysis of PTH. All patients were analyzed polymorphisms CASR. In 166 patients (110 with NL, NL 56 without) were analyzed polymorphisms VDR- ApaI, BsmI, FokI, Cdx2, TaqI. The distribution of genotypes consistent with the condition of Hardy-Weinberg.

Results:

In patients with NL had significantly higher levels of total and ionized calcium $(p=0,014$ and $p=0,0019$, respectively), PTH $(p=$ $0.0004)$ and alkaline phosphatase $(\mathrm{P}=0.09)$, hypophosphatemia $(\mathrm{p}=0.034)$. The level of calcium in the urine did not differ between the groups. Tab.1

The most common in both groups were polymorphisms R990G (23,6\%vs21,8\%) and A986S (29,1\%vs37,9\%), Q1011E(16,4\%vs9,2\%) met the most rare, the differences are not reliable( $p>0,05)$. Not obtained differences in the frequency of genotypes and alleles CASR between the groups $(\mathrm{P}>0.05)$. In the analysis of the frequency of VDR polymorphisms also did not differ between groups ( $\mathrm{p}>0.05)$. The distribution of genotypes and alleles of VDR polymorphisms in the presence and absence of NL was not significantly different ( $\mathrm{p}>0.05$ ). Tab.2,3.

Tab.1 General characteristics of the patients in both groups

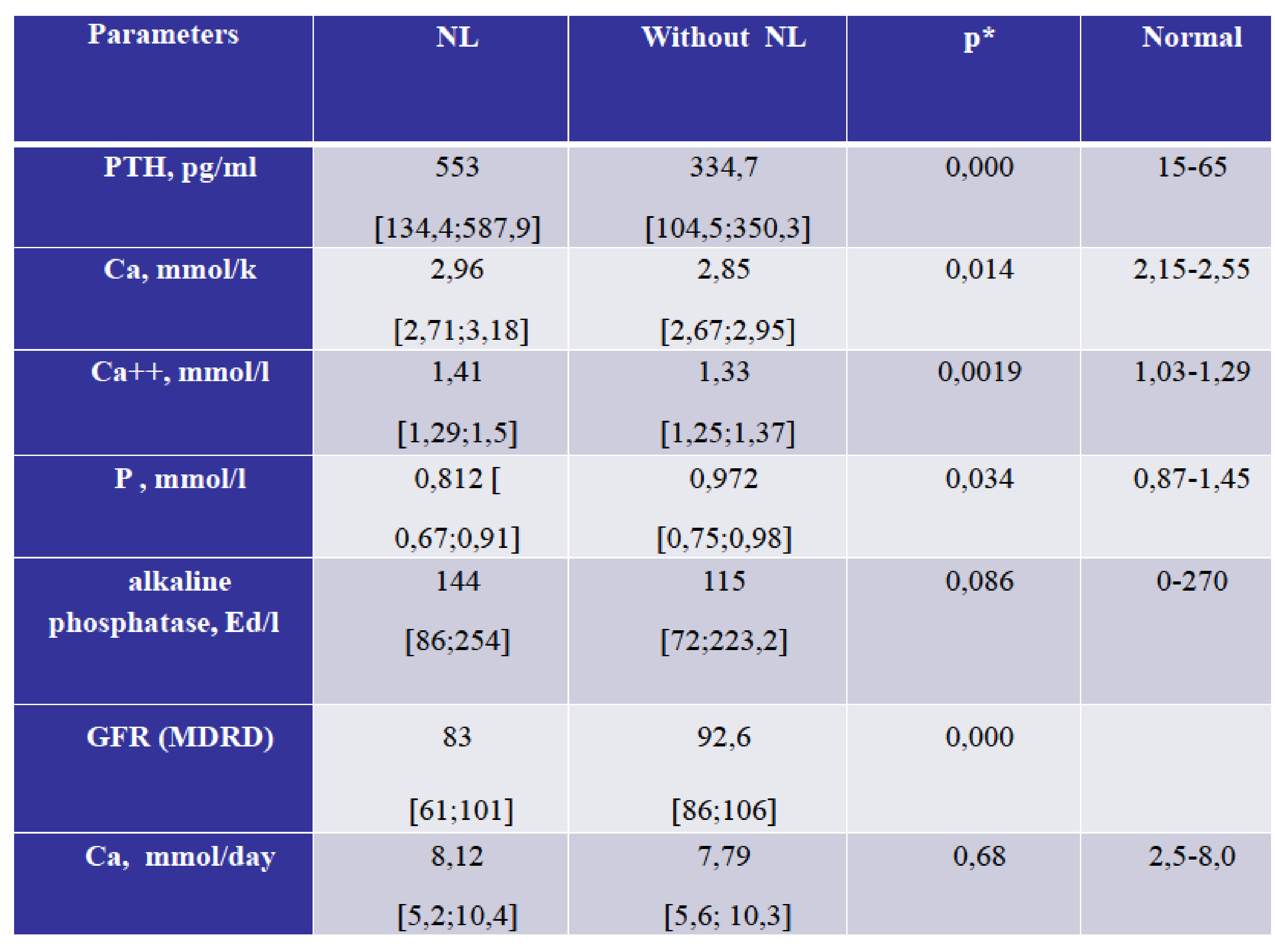

Tab.2.The distribution of genotypes and alleles of CASR in both groups

\begin{tabular}{|c|c|c|c|}
\hline Allele & & Without NL & $\mathbf{p}$ \\
\hline \multicolumn{4}{|c|}{ A986S (rs1801725) } \\
\hline $\mathbf{A A}$ & $70,9 \%$ & $62,1 \%$ & NS \\
\hline AS & $23,6 \%$ & $32,2 \%$ & NS \\
\hline SS & $5,5 \%$ & $5,7 \%$ & NS \\
\hline $\mathbf{A}$ & $82,7 \%$ & $78,2 \%$ & NS \\
\hline $\mathbf{s}$ & $17,3 \%$ & $21,8 \%$ & NS \\
\hline \multicolumn{4}{|c|}{ R990G (rs1042636) } \\
\hline $\mathbf{R R}$ & $76,4 \%$ & $78,2 \%$ & NS \\
\hline RG & $20,9 \%$ & $19,5 \%$ & NS \\
\hline GG & $2,7 \%$ & $2,3 \%$ & NS \\
\hline $\mathbf{R}$ & $86,8 \%$ & $87,9 \%$ & NS \\
\hline $\mathbf{G}$ & $13,2 \%$ & $12,1 \%$ & NS \\
\hline \multicolumn{4}{|c|}{ Q1011E (rs1801726) } \\
\hline QQ & $83,6 \%$ & $90,8 \%$ & NS \\
\hline QE & $14,5 \%$ & $8,0 \%$ & NS \\
\hline EE & $1,8 \%$ & $1,1 \%$ & NS \\
\hline $\mathbf{Q}$ & $90,9 \%$ & $94,8 \%$ & NS \\
\hline $\mathbf{E}$ & $9,1 \%$ & $5,2 \%$ & NS \\
\hline
\end{tabular}

Tab.3.The distribution of genotypes and alleles of VDR in both groups

\begin{tabular}{|c|c|c|c|}
\hline Allele & $\mathbf{N L}$ & Without NL & $\mathbf{p}$ \\
\hline \multicolumn{4}{|c|}{ ApaI (rs7975253) } \\
\hline $\mathbf{A A}$ & $31 \%$ & $28,6 \%$ & NS \\
\hline Aa & $47,8 \%$ & $55,4 \%$ & NS \\
\hline aa & $21,2 \%$ & $17,9 \%$ & NS \\
\hline $\mathbf{A}$ & $54,9 \%$ & $45,1 \%$ & NS \\
\hline a & $54,5 \%$ & $45,5 \%$ & NS \\
\hline \multicolumn{4}{|c|}{ Bsml (rs 1544410) } \\
\hline BB & $42,5 \%$ & $33,3 \%$ & NS \\
\hline Bb & $46 \%$ & $52,6 \%$ & NS \\
\hline bb & $11,5 \%$ & $14 \%$ & NS \\
\hline B & $65,5 \%$ & $59,6 \%$ & NS \\
\hline b & $34,5 \%$ & $40,4 \%$ & NS \\
\hline \multicolumn{4}{|c|}{ Fok I (rs 2228570) } \\
\hline $\mathbf{F F}$ & $37,5 \%$ & $24,5 \%$ & NS \\
\hline Ff & $47,3 \%$ & $62,3 \%$ & NS \\
\hline ff & $15,2 \%$ & $13,2 \%$ & NS \\
\hline $\mathbf{F}$ & $61,2 \%$ & $55,7 \%$ & NS \\
\hline f & $38,8 \%$ & $44,3 \%$ & NS \\
\hline \multicolumn{4}{|c|}{ Taq (rs731236) } \\
\hline TT & $66,7 \%$ & $55,4 \%$ & NS \\
\hline Tt & $28,1 \%$ & $35,7 \%$ & NS \\
\hline tt & $5,3 \%$ & $8,9 \%$ & NS \\
\hline $\mathbf{T}$ & $80,8 \%$ & $72,3 \%$ & NS \\
\hline t & $19,3 \%$ & $26,8 \%$ & NS \\
\hline \multicolumn{4}{|c|}{ Cdx2 (rs 11568820) } \\
\hline GG & $70,8 \%$ & $75 \%$ & NS \\
\hline Ga & $27,4 \%$ & $23,2 \%$ & NS \\
\hline aa & $1,8 \%$ & $1,8 \%$ & NS \\
\hline G & $84,5 \%$ & $86,6 \%$ & NS \\
\hline a & $15,5 \%$ & $13,4 \%$ & NS \\
\hline
\end{tabular}

According to the results revealed a high prevalence of polymorphisms of VDR and CASR patients with PHPT. The development of nephrolithiasis in PHPT not associated with the presence of VDR polymorphisms and CASR. Perhaps the need to search for other genetic markers. Patients with NL characterized by higher levels of calcium and PTH levels.

Vezzoli G, Terranegra A, Arcidiacono T, Soldati L et al. Genetics and calcium nephrolithiasis. J Kidney International. 2011; 80,587-593

Vezzoli G., Tanini A., Ferrucci L. Soldati L et al. Influence of calcium-sensing receptor gene on urinary calcium excretion in stone-foning patients. J Am Soc Nephrol. 2002;13(10):2517-23.

Scilitian Gerragra A, Arcidiacono T, Gambaro G et al. Calcium kidney stones are associated with a haplotype of the calcium-sensing receptor gene region. Nephrol Dial Transplant. 2010; 25 (7): 2245-52 .

5. Mris CC, Gamieri V, Battista C. Primary hyperparathyroidism and the presence of kidney stones are associated with different haplotypes of the calcium-sensing receptor. J.Clin endocrinol Meteab 2007;92(1):277-8

5. Мнрная CC, Пнгарова ЕА, Беляева АB, Мокрьшева НГ и соавторы. Роль кальций-чувствнтельного рецептора в поддержанни снстемы кальцневого
6. Lin Y, Mao Q, Zheng X, Chen H et al Vitamin D Receptor Genetic Polymorphisms and the Risk of Urolithiasis: A Meta-Analysis. Urol Int. 2011;86:249-255.

Sources of Research Support: The work was supported by grant of President of Russian Federation HШ-4527.2014.7 